\title{
Packed Bed Adsorption Column Modeling for Cadmium Removal
}

\author{
Sunil J. Kulkarni ${ }^{*}, a$, Jayant P. Kaware ${ }^{b}$ \\ ${ }^{a}$ Department of Chemical Engineering, Datta Meghe College of Engineering, Airoli, Navi Mumbai, India, 400708 \\ ${ }^{b}$ Bhonsala College of Engineering and Research, Akola, Maharashtra, India, 444001
}

\begin{abstract}
Packed bed adsorption of various pollutants from effluents is efficient and cost effects method. Various factors affecting the removal percentage are initial concentration, flow rate, $\mathrm{pH}$ and bed height. Various models can be used to explain the packed bed adsorption. In the current work, the experimental data obtained for packed bed is fitted in the two model equations. Thomas model and Yoon Nelson model were used and the kinetic parameters were computed. Also effect of the factors like initial concentration, flow rate, $\mathrm{pH}$ and bed height on these kinetic parameters was studied. It was observed that these factors moderately influence the kinetic parameters. The experimental data was well described by these two models.
\end{abstract}

Keywords: kinetic model, parameters, capacity, concentration, saturation.

\section{Introduction}

Heavy metal treatment is one of the major environmental concerns in the fast moving industrial growth. Many industries like metallurgical, fertilizer, pigment, dyes, electroplating, battery, steel, mining, chemical, pharmaceutical, smelting etc. emit heavy metal through their effluent. Heavy metal can cause long term and short term diseases in human being. It is very necessary to minimize the heavy metal pollution in wastewater. Cadmium is one of the heavy metal present in the effluent which can cause renal damage, anemia, hyper tension and liver damage. Cadmium can be removed from the wastewater by various biological, non biological, physical and chemical treatment methods. Adsorption is one of the major technique used for cadmium removal. Packed bed removal of heavy metal is widely studied area of research. Removal of the cadmium in batch and continuous operation has been reported by various investigators[1].Use of various low cost adsorbents like sugarcane bagasse, oil cake, maize corncob, rice husk ash, wheat straw, cashew nut shell was reported to be very effective for cadmium removal[2,3,4,5,6].Packed bed contactors are used for removal of various pollutants in continuous operations. The studies on batch and packed bed removal of heavy metal include the research on isotherm, kinetics and modeling $[7,8,9,10]$. The studies on fixed bed operation for removal of various pollutants like phenol, cadmium, chromium, lead, zinc, organic matter has been reported by various investigators $[11,12,13,14]$. Nwabanne and Igbokwe reported the modeling for lead removal in fixed bed [15].The experimental data was well described by Thomas and Yoon and Nelson kinetic models. An investigation was carried out for modeling and fixed bed column adsorption of chromium (VI) onto orthophosphoric acid-activated lignin by Albadarin et.al. [16]. Thomas model, The modified Dose model and the Bed Depth Service Time (BDST) model were verified for the micro column experiments. They observed that experimental data of individual runs were well represented by the Thomas and Modified dose-response model for variable influent initial $\mathrm{pH}$, ionic strength, initial $\mathrm{Cr}$ (VI) concentration, flow rate and mass of the adsorbent. Bed depth service time model (BDST) was used to analyze the experimental data by Zulfadhly et.al. [17]. In their experiments Pycnoporus sanguineus was used for biosorption of lead, copper and cadmium. BDST model was able to satisfactory explain the experimental data. Modeling of fixed bed removal of lead using nanostructure $\gamma$-alumina was carried out by Sadi et.al.[18]. In their studies they compared Thomas, Yoon-Nelson, and Adams-Bohart models with experimental results. They evaluated the model parameters by

${ }^{*}$ Corresponding author. Tel.: +919664213953

E-mail: suniljayantkulkarni@gmail.com

(C) 2015 International Association for Sharing Knowledge and Sustainability

DOI: $10.5383 /$ ijtee.09.02.004 
linear regression analysis for lead adsorption at different bed heights, initial concentrations, and flow rates. Thomas and Yoon-Nelson models were followed by the processes. In the case of Adams-Bohart model, low correlation coefficient was observed. In our earlier studies packed bed removal of cadmium is carried by using rice husk as an adsorbent was reported[19]. The parameters affecting the fixed bed adsorption like initial concentration, flow rate, initial concentration, and $\mathrm{pH}$ and bed height were analyzed and their effect on solute uptake kinetics was reported. In the current work the data obtained for fixed bed experiments is fitted in two fixed bed models namely Thomas Model and Yoon and Nelson model.

\section{Models}

2.1 Thomas Model

An expression for adsorption column by Thomas is given by following equation[20].

$$
\frac{C}{C o}=\frac{1}{1+\exp \left[\frac{K t}{Q\left(q_{0}{ }^{M-C o V}\right)}\right]}
$$

In this equation, $\mathrm{C}$ is out let concentration at any time $\mathrm{t}$ and $\mathrm{Co}$ is inlet concentration. $\mathrm{V}$ is throughput volume, $\mathrm{Q}$ volumetric flow rate, $\mathrm{K}_{\mathrm{t}}$ is Thomas constant and $\mathrm{q}_{\mathrm{o}}$ is maximum adsorption capacity.

The linear form of this equation is written as

$$
\ln \left(\frac{C_{0}}{C}-1\right)=\frac{K_{t} q_{0} M}{Q}-\frac{K_{T} C_{0}}{Q} V
$$

The plot of $\ln \left(\mathrm{C}_{0} / \mathrm{C}-1\right)$ against $\mathrm{t}$ is a straight-line. The values of the parameters $\mathrm{KT}$, and $\mathrm{q}_{0}$ are estimated from this plot.

\subsection{Yoon and Nelson model}

This model is expressed by following equation [15,19,21].

$$
\begin{aligned}
& \frac{C}{C 0}-\frac{1}{1+\exp [(K(T-t)]} \\
& \ln \frac{C}{C 0-C}=\mathrm{k} \mathrm{t}-\mathrm{T} \mathrm{k}
\end{aligned}
$$

Here, $\mathrm{k}$ is the rate constant and $\mathrm{T}$ is time required for 50 percent adsorbate breakthrough and $t$ is sampling time. The plot of $\ln \frac{C}{C 0-C}$ against time is plotted. The parameters, $\mathrm{T}$ and $\mathrm{k}$ are obtained from the plot.

\section{Methodology}

Packed bed experiments were carried out by using rice husk adsorbent in a column having $5.3 \mathrm{~cm}$ diameter and total $100 \mathrm{~cm}$ height. The effluent was allowed to flow by gravity through the column. The influent sample was synthetically prepared. The analysis was carried out using U.V . spectrophotometer (Elico 159). The data of time verses out let concentration was obtained by varying the parameters like inlet concentration, flow rate, $\mathrm{pH}$ and bed height.

\section{Results and Discussion}

Experiments were carried out in fixed bed with rice husk adsorbent. The effluent was collected after 30 minutes interval and analyzed for cadmium concentration. The samples were collected till the exhaustion of the bed. This was indicated by two to three constant readings at the end of the run. Experiments were carried out by changing initial concentration and keeping all other parameters constant. Similar experiments were carried out for studying the effect of flow rate, $\mathrm{pH}$ and bed height on the Thomas and Yoon Nelson model parameters. For Thomas model, $\ln \left(\frac{C 0}{C}-1\right)$ against time was plotted and for Yoon and Nelson model, $\ln \frac{C}{C 0-C}$ against time was plotted.

\subsection{Effect of initial concentration}

The effect of initial concentration at fixed flow rate, $\mathrm{pH}$ and bed height is shown in fig. $1(\mathrm{a}, \mathrm{b}, \mathrm{c})$. As shown in fig. the maximum adsorption capacity $\mathrm{q}_{0}$, increased with initial concentration. Value of $\mathrm{K}_{\mathrm{t}}$ obtained is in agreement with similar work carried out for various metal ion removal experiments. For concentrations of $10 \mathrm{mg} / \mathrm{l}$ and $30 \mathrm{mg} / \mathrm{l}$, the $\mathrm{R}^{2}$ values were 0.97 and 0.98 respectively, indicating near perfect fit. For $50 \mathrm{mg} / \mathrm{l}$, the deviation is more with $\mathrm{R}^{2}$ value of 0.9. Yoon and Nelson model is represented by fig.5(a,b,c). The data is well represented by this model with $\mathrm{R}^{2}$ values in the range of 0.93-0.96. The time required for 50 percent breakthrough $(\mathrm{T})$ decreased with initial concentration.

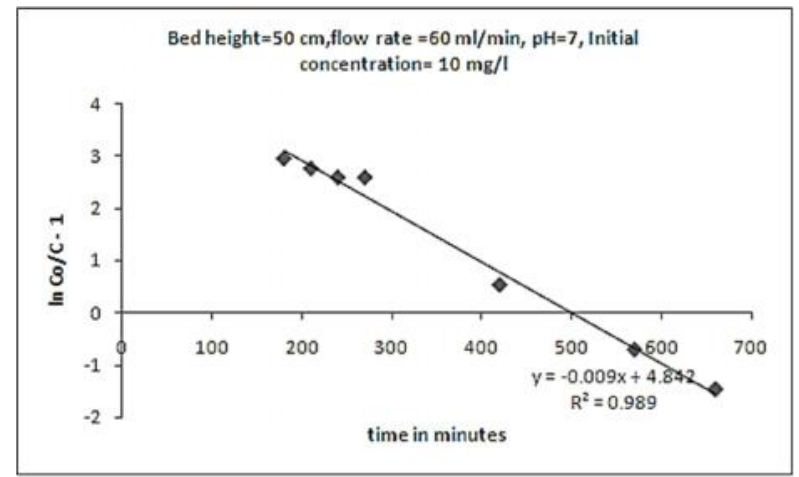

Fig.1a: Thomas Model at initial concentrations of $10 \mathrm{mg} / \mathrm{l}$

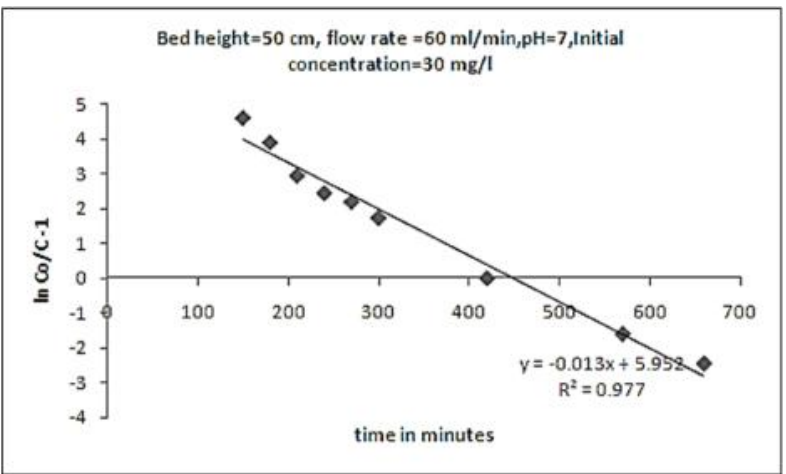

Fig.1b: Thomas Model at initial concentrations of $30 \mathrm{mg} / \mathrm{l}$ 


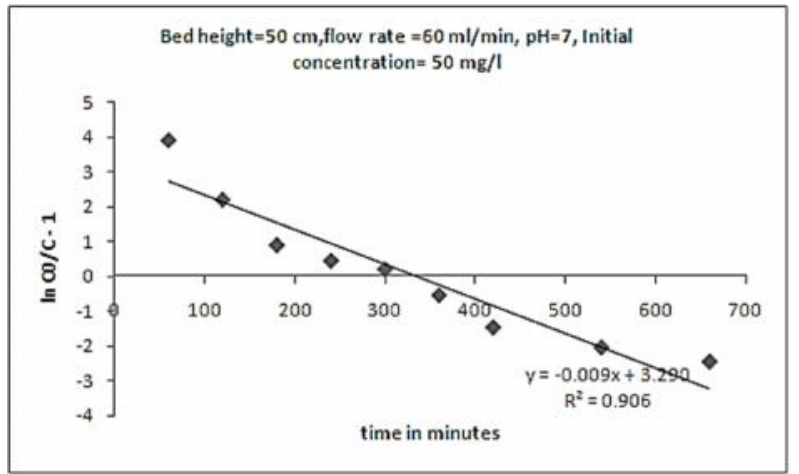

Fig.1c: Thomas Model at initial concentration of $50 \mathrm{mg} / \mathrm{l}$

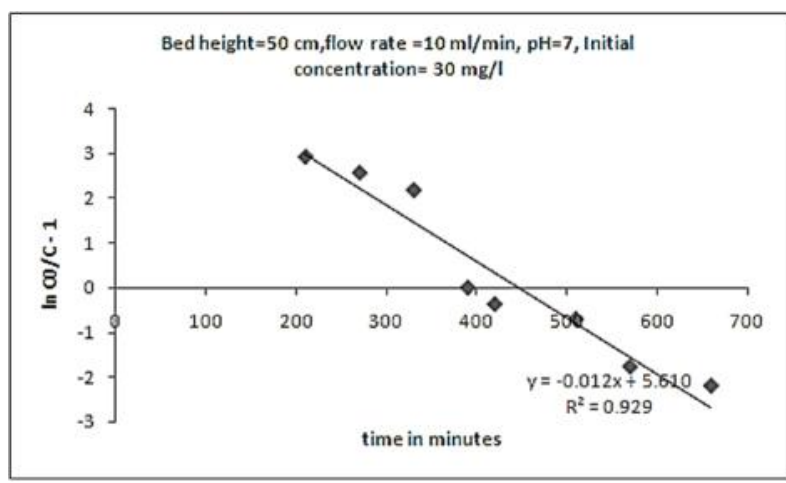

Fig.2a: Thomas Model at flow rate of $10 \mathrm{ml} / \mathrm{min}$

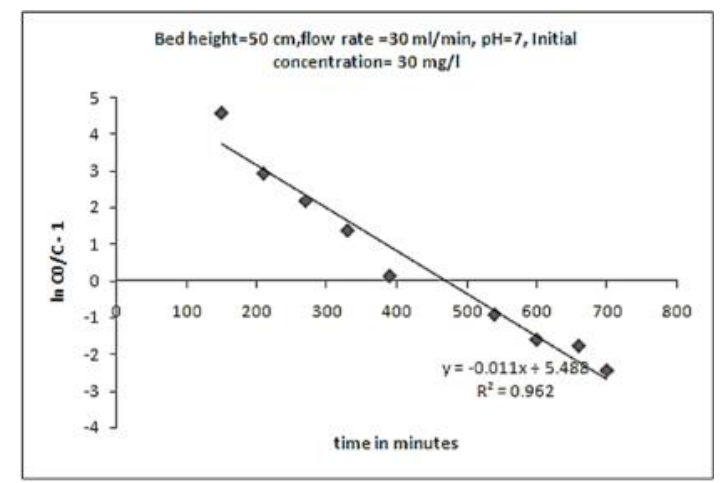

Fig.2b: Thomas Model at flow rate of $30 \mathrm{ml} / \mathrm{min}$

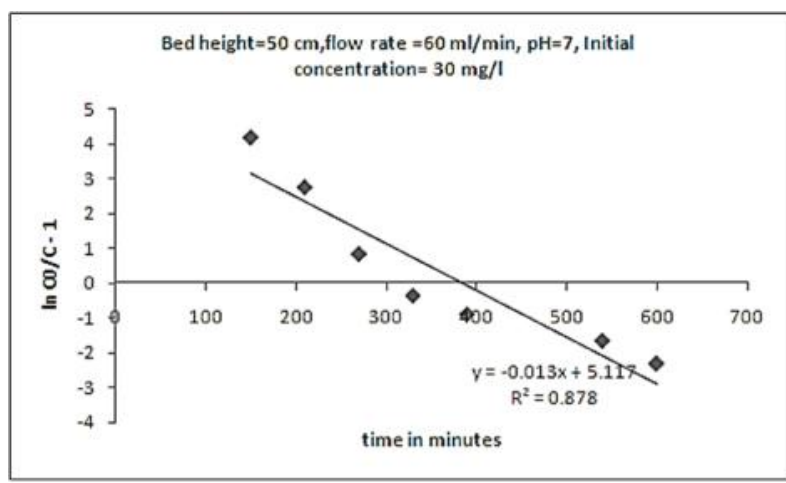

Fig.2c: Thomas Model at flow rate of $60 \mathrm{ml} / \mathrm{min}$

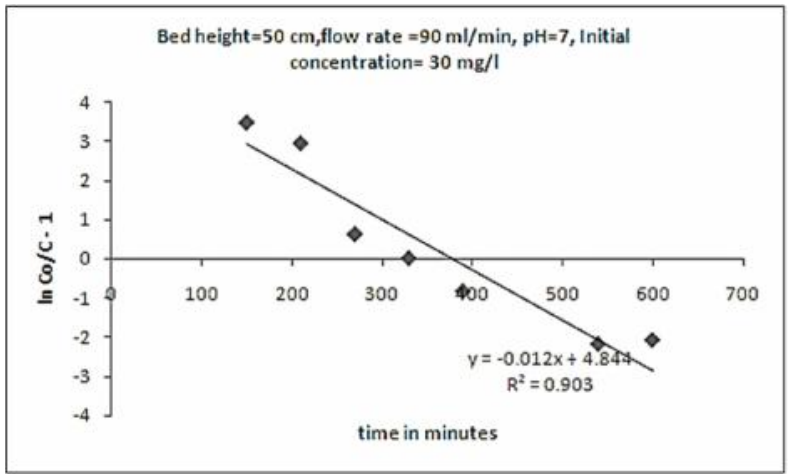

Fig.2d: Thomas Model at flow rate of $90 \mathrm{ml} / \mathrm{min}$

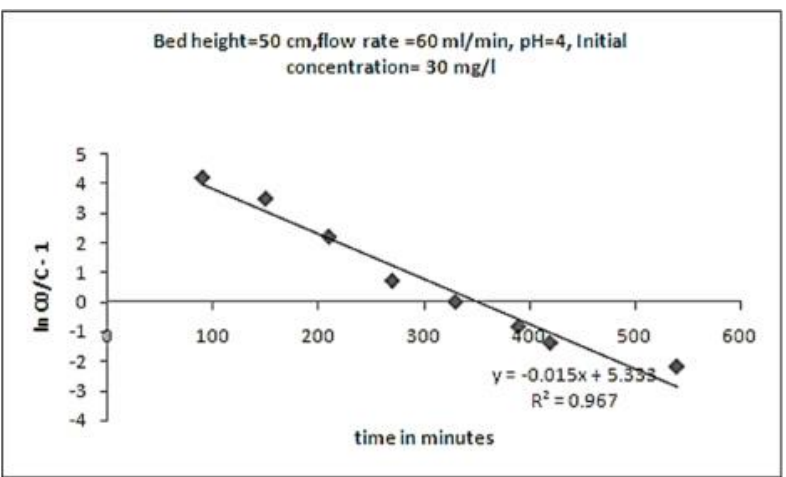

Fig.3 a: Thomas Model at $\mathrm{pH}$ value of 4

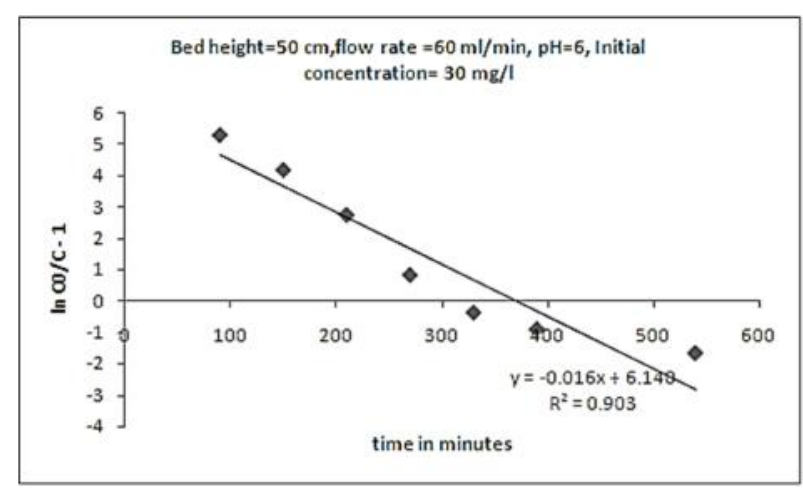

Fig.3 b: Thomas Model at $\mathrm{pH}$ value of 6

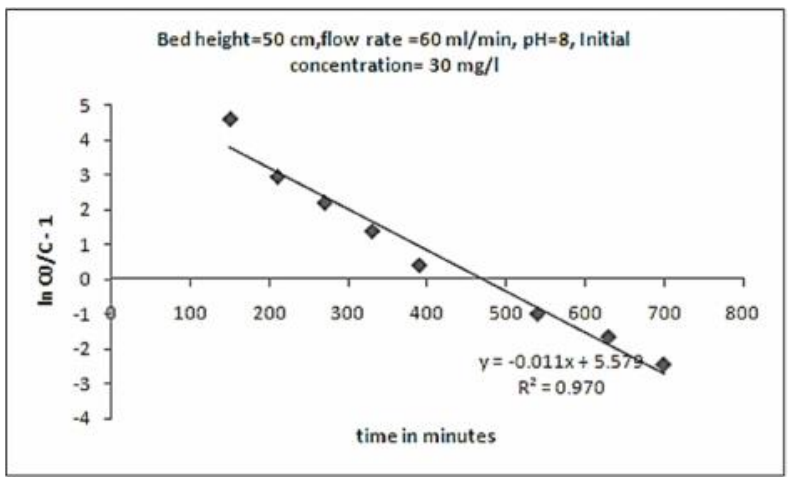

Fig.3 c: Thomas Model at $\mathrm{pH}$ value of 8 


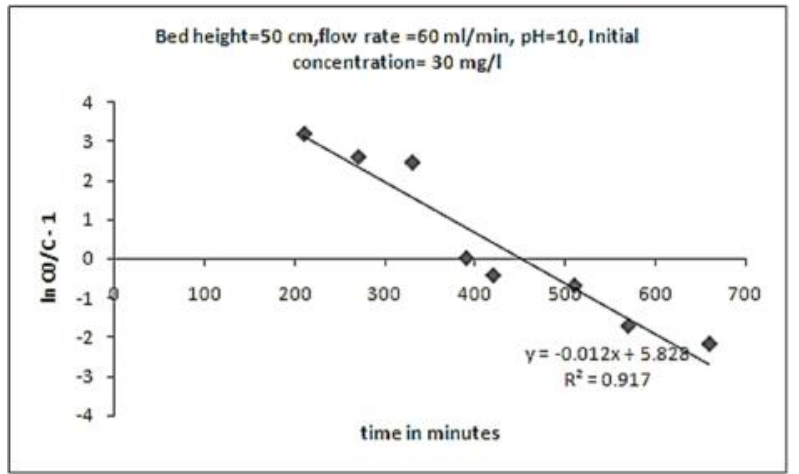

Fig.3 d: Thomas Model at $\mathrm{pH}$ value of 10

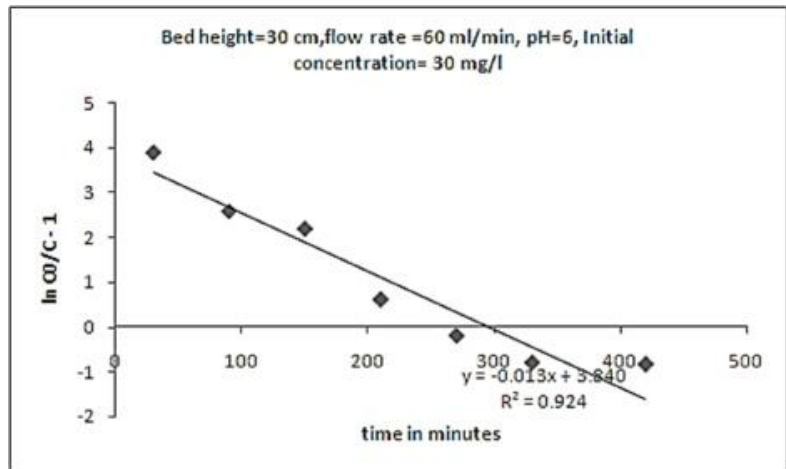

Fig.4 a: Thomas Model for bed height $030 \mathrm{~cm}$

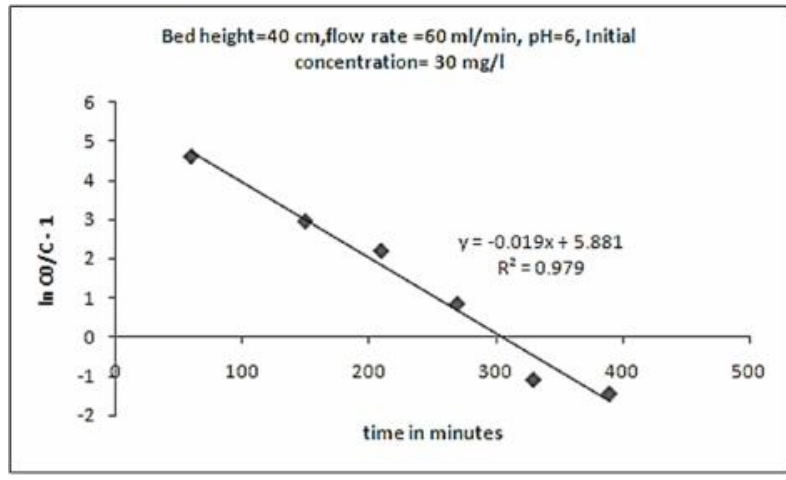

Fig.4 b: Thomas Model for bed height of $40 \mathrm{~cm}$

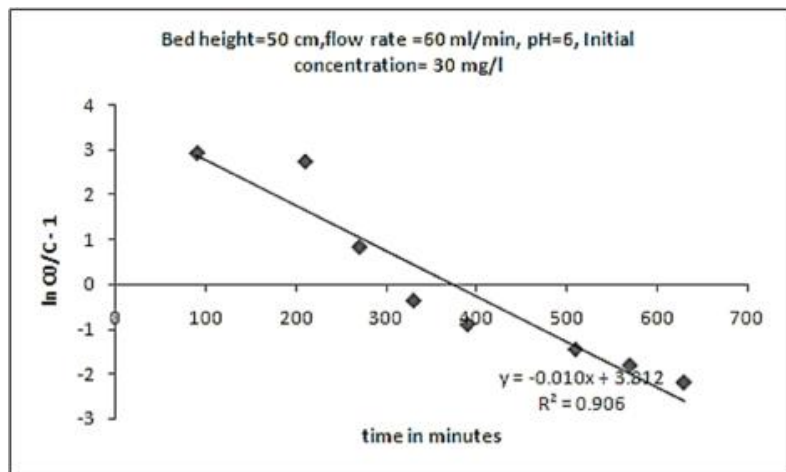

Fig.4 c: Thomas Model for bed height 0 f $50 \mathrm{~cm}$

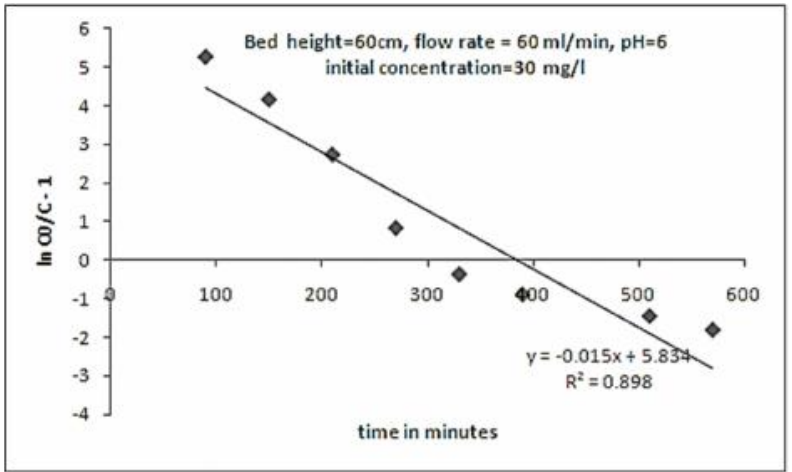

Fig.4 d: Thomas Model for bed height of $60 \mathrm{~cm}$

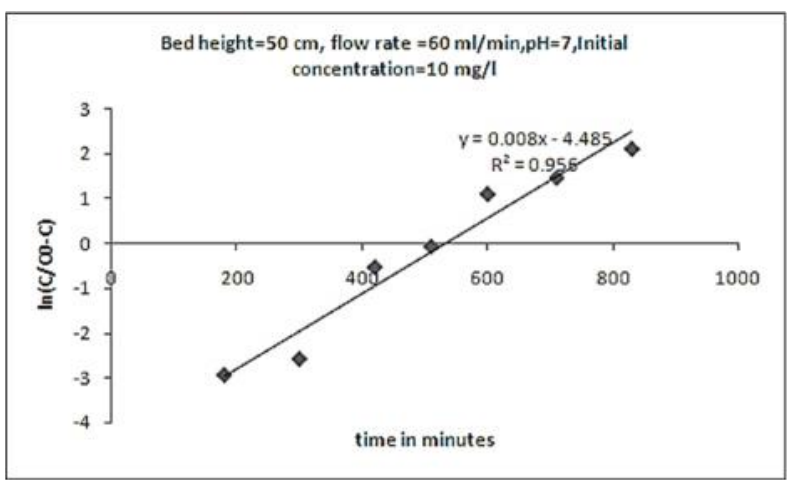

Fig 5 a: Yoon \& Nelson at initial concentration of $10 \mathrm{mg} / 1$

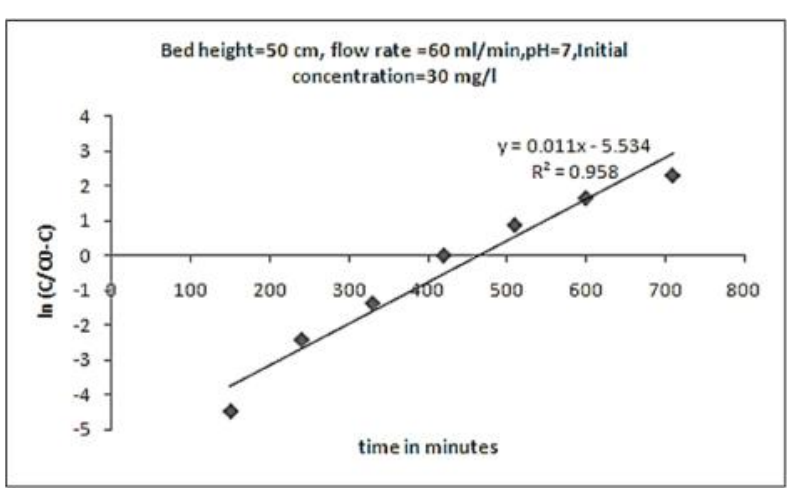

Fig 5 b: Yoon \& Nelson at initial concentration of $30 \mathrm{mg} / \mathrm{l}$

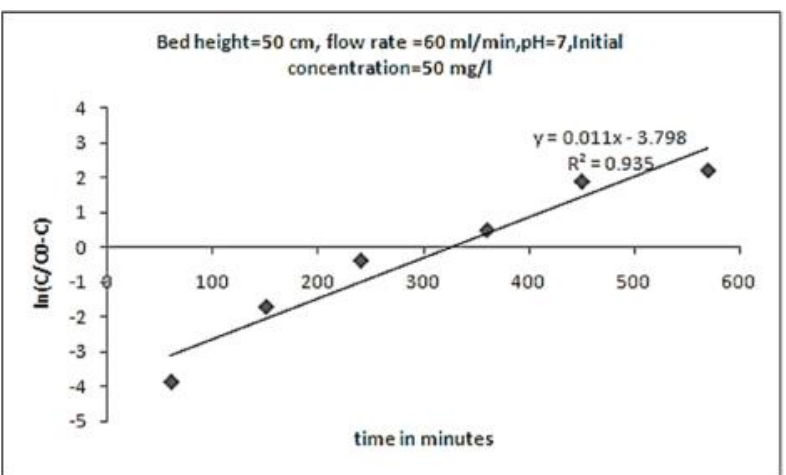

Fig 5 c: Yoon \& Nelson at initial concentration of $50 \mathrm{mg} / \mathrm{l}$ 


\subsection{Effect of flow rate}

In case of Thomas model, as shown in fig.2(a,b,c,d), with increase in flow rate $q_{0}$ increased. There was very small increase in $\mathrm{K}_{\mathrm{t}}$ value. In case of Yoon and Nelson model , as shown in fig.6(a,b,c,d), for flow rate increase from $30 \mathrm{ml} / \mathrm{min}$ to $90 \mathrm{ml} / \mathrm{min}$, there was decrease in $\mathrm{T}$, time required for 50 percent breakthrough. For these data $\mathrm{R}^{2}$ values were in the range of 0.93 to 0.96 , indicating perfect fit. For higher flow rate $(90 \mathrm{mg} / \mathrm{l})$ the deviation was more $\left(\mathrm{R}^{2}=0.89\right)$. According to the observations, flow rate has significant effect on the Thomas and Yoon Nelson parameters.

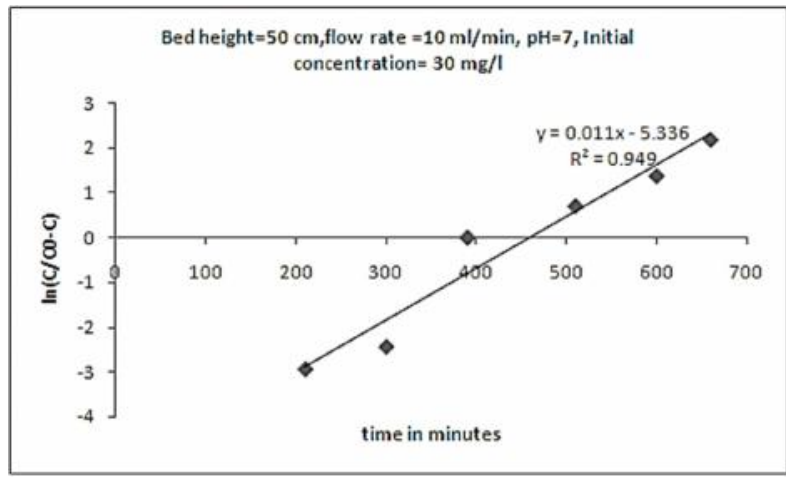

Fig 6 a: Yoon \& Nelson at flow rate of $10 \mathrm{ml} / \mathrm{min}$

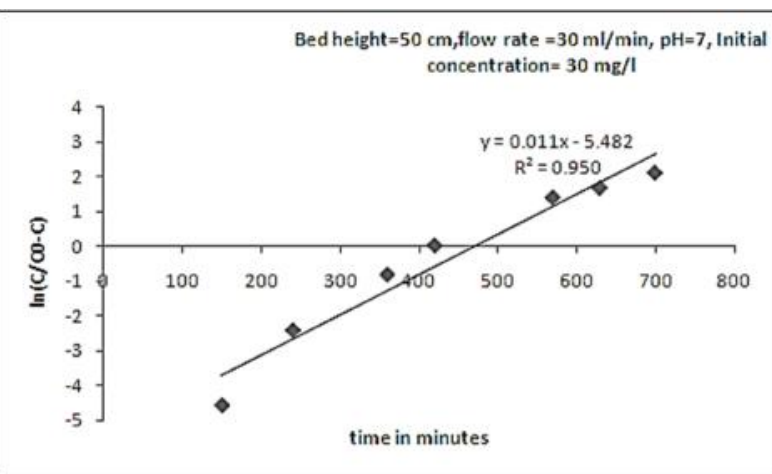

Fig 6 b: Yoon \& Nelson at flow rate of $30 \mathrm{ml} / \mathrm{min}$

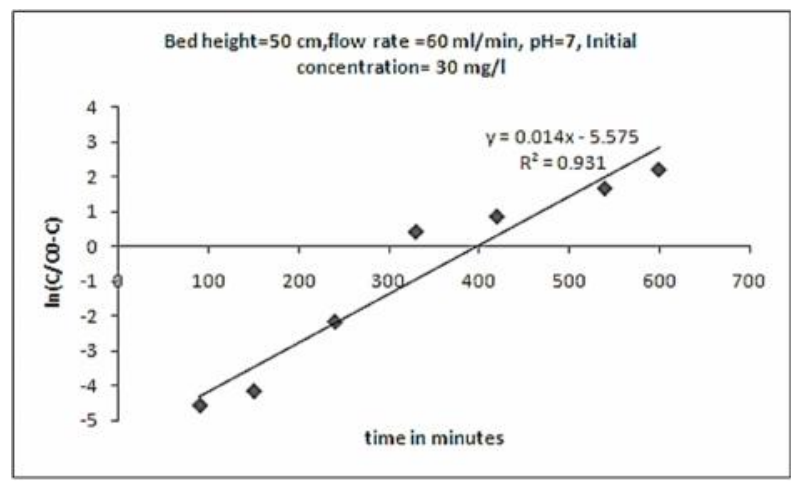

Fig 6 c: Yoon \& Nelson at flow rate of $60 \mathrm{ml} / \mathrm{min}$

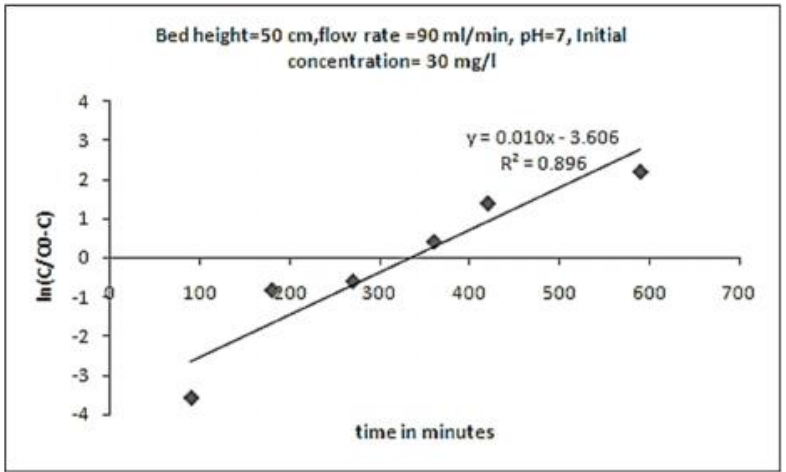

Fig $6 \mathrm{~d}$ : Yoon \& Nelson at flow rate of $90 \mathrm{ml} / \mathrm{min}$

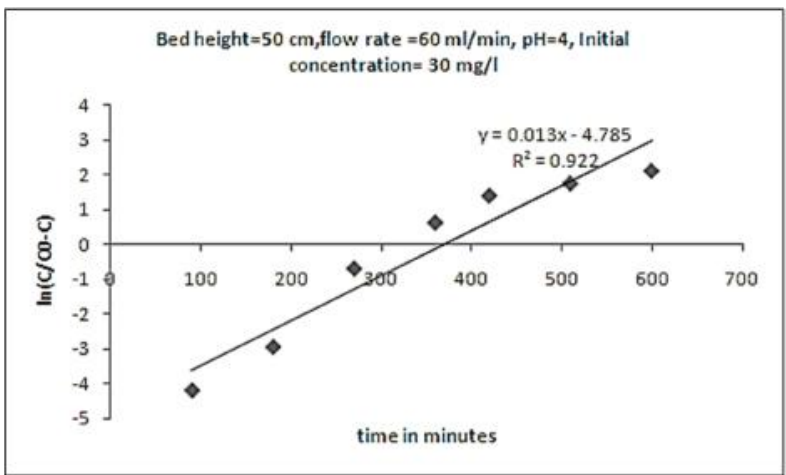

Fig 7 a : Yoon \& Nelson at pH value of 4

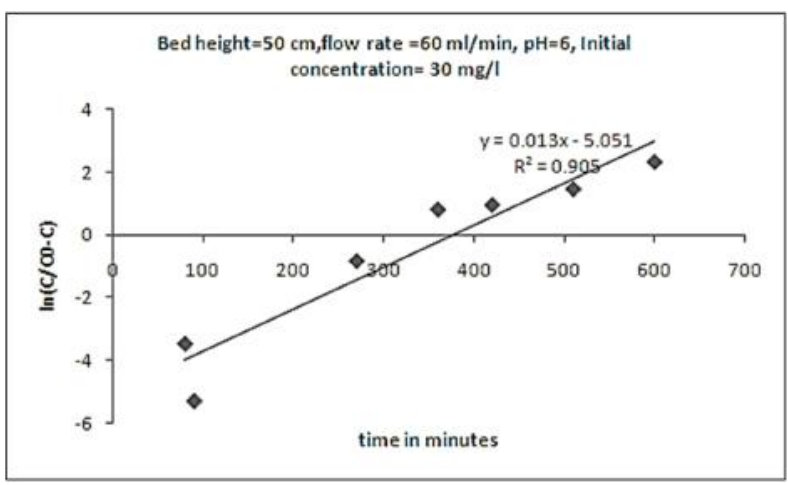

Fig 7 b : Yoon \& Nelson at $\mathrm{pH}$ value of 6

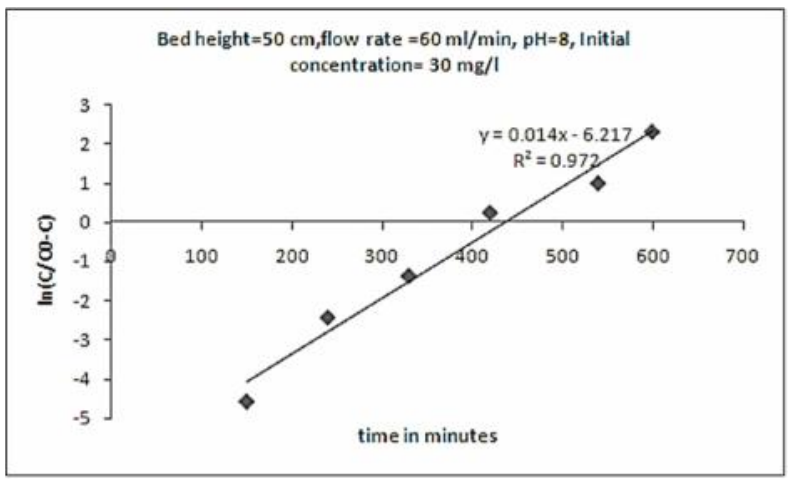

Fig $7 \mathrm{c}:$ Yoon \& Nelson at $\mathrm{pH}$ value of 8 


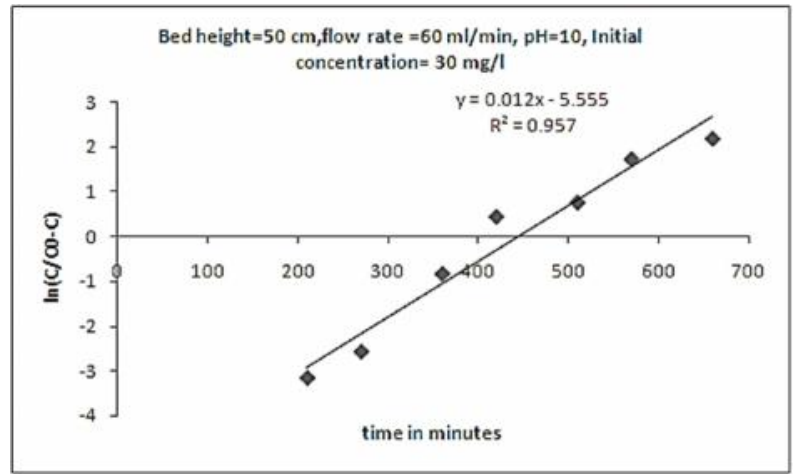

Fig $7 \mathrm{~d}$ : Yoon \& Nelson at pH value of 10

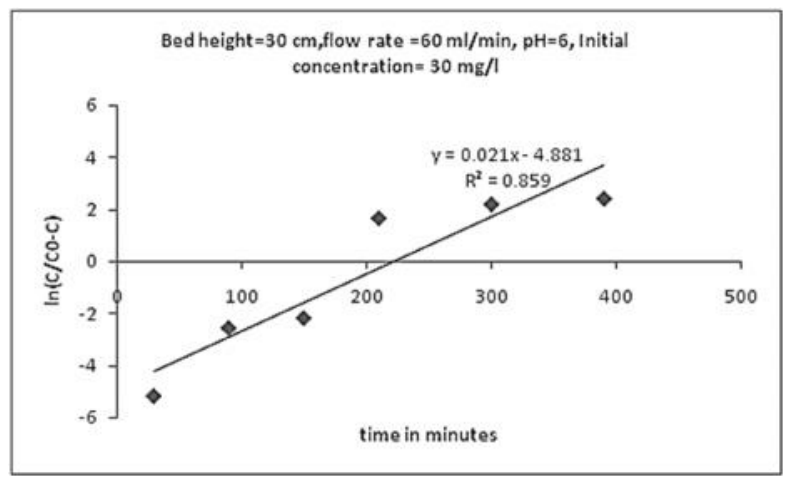

Fig 8 a : Yoon \& Nelson for bed height of $30 \mathrm{~cm}$

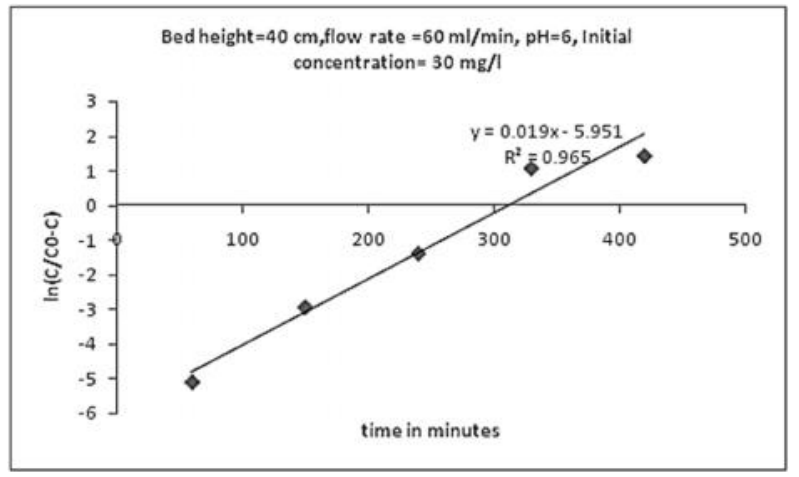

Fig 8 b: Yoon \& Nelson for bed height of $40 \mathrm{~cm}$

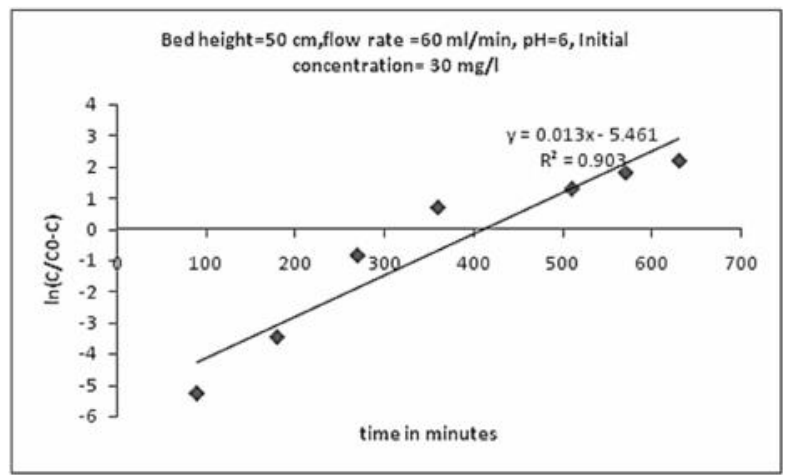

Fig 8 c: Yoon \& Nelson for bed height of $50 \mathrm{~cm}$

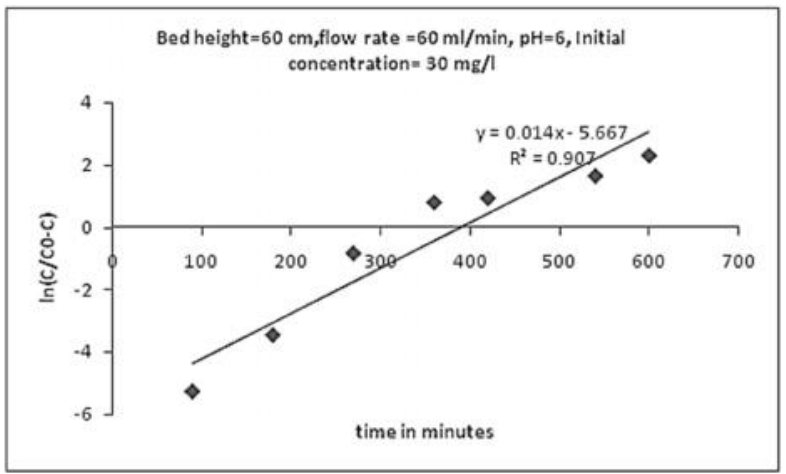

Fig. $8 \mathrm{~d}$ : Yoon \& Nelson for bed height of $60 \mathrm{~cm}$

\subsection{Effect of $\mathrm{pH}$}

Thomas model for $\mathrm{pH}$ values is plotted in fig.3(a,b,c,d). The value of $\mathrm{q}_{0}$ increased in $\mathrm{pH}$ range of 6 to 8 . As shown in fig $7(\mathrm{a}, \mathrm{b}, \mathrm{c}, \mathrm{d})$, for Yoon-Nelson model, constant $\mathrm{K}$ is not much affected by the $\mathrm{pH}$. The value of $\mathrm{T}$, time for 50 percent breakthrough is minimum for $\mathrm{pH}$ values of 4 to 6 . This value increased significantly for further increase in $\mathrm{pH}$ value.

\subsection{Effect of Bed Height}

Bed height has significant effect on kinetic parameters. Thomas Model parameters at various bed heights are plotted in fig. 4(a,b,c,d). With increase in bed height, the adsorption capacity $\left(\mathrm{q}_{0}\right)$ decreased. The Yoon and Nelson model is satisfactory for bed height between $40 \mathrm{~cm}$ to $50 \mathrm{~cm}$. The Yoon Nelson model is represented in fig. 8(a,b,c,d).

Table 1:Effect of Initial Concentration for Thomas Model

\begin{tabular}{|c|c|c|c|}
\hline Parameters & \multicolumn{3}{|c|}{$\begin{array}{c}\text { Initial Concentration at fixed bed } \\
\text { height, } \mathrm{pH} \text { and flow rate }(\mathrm{mg} / \mathrm{l})\end{array}$} \\
\hline & 10 & 30 & 50 \\
\hline $\mathrm{K}_{\mathrm{t}}(\mathrm{ml} / \mathrm{min} / \mathrm{mg})$ & 0.9 & 0.43 & 0.18 \\
\hline $\mathrm{q}_{0}(\mathrm{mg} / \mathrm{g})$ & 1.42 & 3.77 & 4.98 \\
\hline $\mathrm{R}^{2}$ & 0.98 & 0.97 & 0.90 \\
\hline
\end{tabular}

Table 2: Effect of Flow Rate for Thomas Model

\begin{tabular}{|c|c|c|c|c|}
\hline Parameters & \multicolumn{4}{|c|}{$\begin{array}{c}\text { Flow rate at fixed bed height, } \mathrm{pH} \text { and } \\
\text { initial concentration }(\mathrm{ml} / \mathrm{min})\end{array}$} \\
\hline & 10 & 30 & 60 & 90 \\
\hline $\mathrm{K}_{\mathrm{t}}(\mathrm{ml} / \mathrm{min} / \mathrm{mg})$ & 0.4 & 0.36 & 0.43 & 0.4 \\
\hline $\mathrm{q}_{0}(\mathrm{mg} / \mathrm{g})$ & 0.67 & 2.04 & 3.24 & 4.95 \\
\hline $\mathrm{R}^{2}$ & 0.92 & 0.96 & 0.87 & 0.90 \\
\hline
\end{tabular}

Table3:Effect of pH for Thomas Model

\begin{tabular}{|c|c|c|c|c|}
\hline Parameters & \multicolumn{4}{|c|}{$\begin{array}{c}\mathrm{pH} \text { at fixed bed height, initial } \\
\text { concentration and flow rate }\end{array}$} \\
\hline & 4 & 6 & 8 & 10 \\
\hline $\mathrm{K}_{\mathrm{t}}(\mathrm{ml} / \mathrm{min} / \mathrm{mg})$ & 0.5 & 0.53 & 0.36 & 0.4 \\
\hline $\mathrm{q}_{0}(\mathrm{mg} / \mathrm{g})$ & 2.91 & 2.72 & 4.15 & 3.97 \\
\hline $\mathrm{R}^{2}$ & 0.96 & 0.90 & 0.97 & 0.91 \\
\hline
\end{tabular}

Table 4: effect of Bed Height for Thomas Model

\begin{tabular}{|c|c|c|c|c|}
\hline Parameters & \multicolumn{4}{|c|}{$\begin{array}{l}\text { Bed height at fixed initial concentration, flow } \\
\text { rate and } \mathrm{pH}(\mathrm{cm})\end{array}$} \\
\hline & 30 & 40 & 50 & 60 \\
\hline $\begin{array}{c}\mathrm{K} \\
(\mathrm{ml} / \mathrm{min} / \mathrm{mg})\end{array}$ & 0.43 & 0.63 & 0.33 & 0.5 \\
\hline $\mathrm{q}_{0}(\mathrm{mg} / \mathrm{g})$ & 4.06 & 3.18 & 3.14 & 2.65 \\
\hline $\mathrm{R}^{2}$ & 0.92 & 0.97 & 0.90 & 0.89 \\
\hline
\end{tabular}




\section{Conclusion}

Thomas and Yoon \& Nelson model parameters are shown in tables 1 to 8 . It is observed that the parameters like initial concentration, flow rate, bed height and $\mathrm{pH}$ affect the model parameters significantly. The values of model parameters are in agreement with similar work carried out for various metal ions and adsorbents $[18,20)$. The experimental data also fits well in both the models with exception of three experimental runs out of total 30 runs. The time required for 50 percent break through decreased with flow rate and initial concentration with only one exception. The adsorption capacity decreased with bed height and increased with initial concentration and flow rate.

Table 5:Effect of Initial Concentration for Yoon Nelson Model

\begin{tabular}{|l|l|l|l|}
\hline Parameters & \multicolumn{3}{|l}{$\begin{array}{l}\text { Initial Concentration at fixed bed } \\
\text { height, } \mathrm{pH} \text { and flow rate }(\mathrm{mg} / \mathrm{l})\end{array}$} \\
\hline & 10 & 30 & 50 \\
\hline $\mathrm{K}\left(/ \mathrm{min}^{-1}\right)$ & 0.008 & 0.011 & 0.011 \\
\hline $\mathrm{T}(\mathrm{min})$ & 185.6 & 498 & 345.27 \\
\hline $\mathrm{R}^{2}$ & 0.956 & 0.958 & 0.935 \\
\hline
\end{tabular}

Table 6: Effect of Flow rate for Yoon Nelson Model

\begin{tabular}{|l|l|l|l|l|}
\hline Parameters & \multicolumn{4}{|l}{$\begin{array}{l}\text { Flow rate at fixed bed height, } \mathrm{pH} \text { and } \\
\text { initial concentration }(\mathrm{ml} / \mathrm{min})\end{array}$} \\
\hline & 10 & 30 & 60 & 90 \\
\hline $\mathrm{K}\left(/ \mathrm{min}^{-1}\right)$ & 0.011 & 0.011 & 0.014 & 0.01 \\
\hline $\mathrm{T}(\mathrm{min})$ & 485 & 498.3 & 398.2 & 368 \\
\hline $\mathrm{R}^{2}$ & 0.94 & 0.95 & 0.93 & 0.89 \\
\hline
\end{tabular}

Table 7:Effect of pH for Yoon Nelson Model

\begin{tabular}{|l|l|l|l|l|l|}
\hline Parameters & \multicolumn{2}{|c|}{$\mathrm{pH}$ at fixed bed height, initial } \\
& \multicolumn{1}{|c|}{ concentration and flow rate } & \\
\hline & 4 & 6 & 8 & 10 \\
\hline $\mathrm{K}\left(/ \mathrm{min}^{-1}\right)$ & 0.013 & 0.012 & 0.014 & 0.012 \\
\hline $\mathrm{T}(\mathrm{min})$ & 368 & 388 & 444 & 463 \\
\hline $\mathrm{R}^{2}$ & 0.922 & 0.905 & 0.972 & 0.957 \\
\hline
\end{tabular}

Table 8:Effect of Bed Height for Yoon Nelson Model

\begin{tabular}{|l|l|l|l|l|}
\hline Parameters & \multicolumn{2}{|l|}{$\begin{array}{l}\text { Bed height at fixed initial } \\
\text { concentration, flow rate and } \\
\mathrm{pH}(\mathrm{cm})\end{array}$} \\
\hline & 30 & 40 & 50 & 60 \\
\hline $\mathrm{K}\left(/ \mathrm{min}^{-1}\right)$ & 0.021 & 0.019 & 0.013 & 0.014 \\
\hline $\mathrm{T}(\mathrm{min})$ & 232 & 313 & 420 & 404 \\
\hline $\mathrm{R}^{2}$ & 0.859 & 0.965 & 0.903 & 0.907 \\
\hline
\end{tabular}

\section{Refrences}

[1] Sunil J. Kulkarni, Dr. Jayant P. Kaware, A Review on Research for Cadmium Removal from Effluent ",International Journal of Engineering Science and Innovative Technology (IJESIT),2013, 2(4),pp.465-470.

[2] Garg U, Kaur MP, Jawa GK, Sud D, Garg V.K.,Removal of cadmium (II) from aqueous solutions by adsorption on agricultural waste biomass, Journal of Hazards Mater,2008; 154(1-3)1149-57.

[3] N. Suganthi,Fixed Bed Column Adsorption Studies for Removal of Metal Ions using Tamarind Seeds, Coromandal Journal of Science,2012, 1(1),65-71.
[4] Abbas H. Sulaymon, Shahlaa E. Ebrahim, Tariq J. Al Musawi ,Sama M. Abdullah, Removal of Lead, Cadmium, and Mercury Ions Using Biosorption, Iraqi Journal of Chemical and Petroleum Engineering,2010, 1(2)1-13.

[5] H. Muhamad, H. Doan, A. Lohi, Batch And Fixed-Bed Column Biosorption Of $\mathrm{Cd} 2+$ and $\mathrm{Cu} 2+$ Onto Wheat Straw, Chemical Engineering Journal,2010,158(3),369377.

[6] Kumar P.S.,Subramaniam, R.,Vasanthakumar S.,Selvaraj D. K., Arukkani M.,Subramanian S., Removal of cadmium(II) from aqueous solution by agricultural waste cashew nut shell, Korean J Chemical Engineering,2012,29(.6),756-768.

[7] Sunil J. Kulkarni, Dr.Jayant P. Kaware, Adsorption for Cadmium Removal from Effluent- A Review, International Journal of Science, Engineering and Technology Research (IJSETR), 2013, 2(10), pp.18401844.

[8] Gupta V. K, Jain CK, Ali, Sharma M, Saini VK, Removal of cadmium and nickel from wastewater using bagasse fly ash--a sugar industry waste, Water Res.,2003, 37,p.403844.

[9] Srivastava V.C., Mall I.D., Mishra I.M., Equilibrium modelling of single and binary adsorption of cadmium and nickel onto bagasse fly ash", Chemical Engineering Journal,2006, 117, pp.79-91.

[10] Shafiei F.,Ghadaksaz S.,Rice Husk, Application For Biosorptive Removal Of Cadmium In Different Experimental Conditions, The 1th International and The 4th National Congress on Recyclying of Organic Waste in Agrriculture, Iran, 2012,1-3, pp.26 - 27.

[11] S.J. Kulkarni, Dr.J.P. Kaware, Fixed Bed Removal of Heavy Metal- a Review, International Journal of Research (IJR),,2014, 1(6), pp.861-871.

[12] Abbas H. Sulaymon, Shahlaa E. Ebrahim, Tariq J. Al Musawi ,Sama M. Abdullah, Removal of Lead, Cadmium, and Mercury Ions Using Biosorption, ,Iraqi Journal of Chemical and Petroleum Engineering, 2010,.11(2), pp.113.

[13] Sunil J. Kulkarni, Removal of phenol from Effluent in Fixed Bed: A Review, International Journal of Engineering Research and General Science, 2014, 2(5), pp.35-39.

[14] Shahlaa E. Ebrahim, Modeling the Removal of Phenol by Natural Zeolitein Batch and Continuous Adsorption Systems, Journal of Babylon University/ Engineering Sciences,2013, 21 (1), pp.249-263.

[15] Nwabanne, J. T. Igbokwe, P. K., Adsorption Performance of Packed Bed Column for the removal of Lead (ii) using oil Palm Fibre, International Journal of Applied Science and Technology, 2012, 2(5), pp. 106-115. 
[16] Ahmad B. Albadarin, Chirangano Mangwandi, Alaa H. Al-Muhtaseb, Gavin M. Walker, Stephen J. Allen and Mohammad N.M. Ahmad, Modelling and Fixed Bed Column Adsorption of $\mathrm{Cr}(\mathrm{VI})$ onto Orthophosphoric Acid-activated Lignin, Chinese Journal of Chemical Engineering, 2012,20(3), pp.469-477.

[17] Z. Zulfadhly, M.D. Mashitah,S. Bhatia,, Heavy metals removal in fixed-bed column by the macro fungus Pycnoporus sanguineus, Environmental Pollution,2001,112(3) pp.463-470.

[18] Zahra Saadi, Reyhane Saadi and Reza Fazaeli, Fixed-bed adsorption dynamics of $\mathrm{Pb}$ (II) adsorption from aqueous solution using nanostructured $\gamma$-alumina, Journal Of Nanostructure in Chemistry,2013, 3(1), pp.1-8.
[19] Sunil J. Kulkarni , Jayant P. Kaware, Analysis of Packed Bed Adsorption Column with Low Cost Adsorbent for Cadmium Removal, Int. J. of Thermal \& Environmental Engineering ,2015, 9(1), pp.17-24.

[20] Kavak, D., \& Öztürk, N., Adsorption of boron from aqueous solution by sepirolite: II. Column studies, Illuslrararasi. Bor. Sempozyumu, 2004, 23-25, pp.495500 .

[21] Aksu, Z., Go"nen, F., Biosorption of phenol by immobilized activated sludge in a continuous packed bed: prediction of breakthrough curves., Process Biochem.,2004, 39 (5),pp. 599-613. 